\title{
Inter-annual Variability of Planktonic Copepods in a Tropical Bay in Southeastern Brazil
}

\author{
Cristina de Oliveira Dias *and Sérgio Luiz Costa Bonecker \\ Departamento de Zoologia; Instituto de Biologia; Universidade Federal do Rio de Janeiro; CCS; Bloco A; Cidade \\ Universitária; crcldias@biologia.ufrj.br; 21941-590; Rio de Janeiro - RJ - Brasil
}

\begin{abstract}
The aim of this work was to study the structure of the copepod community in relation to hydrographic conditions in Espírito Santo Bay, from 1993 to 1997. Zooplankton samples were obtained in the horizontal tows four times a year, using a 200 um net. Temperature, salinity and dissolved oxygen were determined in the water samples. The overall mean density of the copepods was 9,085 ind. $\mathrm{m}^{-3}$ with the peaks exceeding $15,000 \mathrm{ind} . \mathrm{m}^{-3}$ in the summer and autumn during the first three years (1993 - 1995). The PCA analysis was used to relate the environmental conditions with the distribution of the copepods. The increases in the abundant species, namely Acartia lilljeborgi, Oithona hebes, Oithona oculata, Paracalanus quasimodo, Parvocalanus crassirostris and Euterpina acutifrons, were related to the decreases in the diversity. The spatial and temporal variations of the temperature and salinity influenced the abundance of the species during the five years of the sampling and the dominant species alternated in abundance.
\end{abstract}

Key words: Copepoda, Crustacea, Spatial-temporal variation, Espírito Santo Bay, Brazil

\section{INTRODUCTION}

The Espírito Santo Bay is a coastal system located in the south-eastern Brazil. The bay is economically important because of the location of one of the busiest ports in Brazil (Tubarão) at its entrance. The region is popular for recreation and fishing. However, it is suffering degradation caused by the industry and household wastes. Ironore pellets, coal particles and oil are found in the region (Nalesso and Mazioli, 2000; Pereira et al. 2000; Nassar et al. 2003; Jesus et al. 2004).

The investigations on the coastal plankton of the state of Espírito Santo, mostly on the numerical

\footnotetext{
Author for correspondence
}

distribution of the groups or selected taxa, have been conducted since 1986. Espírito Santo Bay has been the subject of general descriptive studies on the planktonic communities in order to evaluate the environmental quality (Bonecker et al. 1987, 1991). Dias (1994, 1999) reported on the temporal-spatial distribution of the copepods and the occurrence of the morphological abnormalities in Acartia lilljeborgi. The determination of the factors driving the inter-annual variability in the marine zooplankton is an important issue (Christou, 1998). In the coastal waters of southeastern Brazil, long-term studies on zooplankton are only a few (Dias, 1994; Lopes, 1994; Bassani et al. 1999; Dias et al. 1999; Schutze and Ramos, 
1999; Valentin et al. 1999). The south-east coast of Brazil, especially the estuarine areas located near the large urban concentrations and important commercial ports, has been strongly impacted by the human activities (Carmo, 1987; Tommasi, 1987; Carmo et al. 1994).

The aim of this work is to study the occurrence, pattern of abundance, seasonality and temporal distribution of the copepods in the Espírito Santo bay estuary, from the data collected over a fiveyear period. Several additional questions were also addressed: Was the copepod community different from a previous study in 1986-1987? Did physical and chemical parameters influence the copepod population?

\section{MATERIALS AND METHODS}

Espírito Santo Bay $\left(20^{\circ} 15^{\prime} \mathrm{S}-40^{\circ} 14^{\prime} \mathrm{W}\right.$ and $\left.20^{\circ} 18^{\prime} \mathrm{S}-40^{\circ} 17^{\prime} \mathrm{W}\right)$ is located in the city of Vitória (Brazil). The bay's area is approximately $20 \mathrm{~km}^{2}$; its depth is less than $10 \mathrm{~m}$ and its entrance is $3.5 \mathrm{~km}$ wide. The bay's waters are frequently renewed because of the proximity of the open sea (Jesus et al. 2004).

The sampling program was carried out in the summer, fall, winter and spring of 1993 to 1997 at eight stations. Sampling was done at four stations inside (stations 1, 2, 3 and 4) and four other stations outside (5, 6, 7 and 8$)$ the bay. The zooplankton samples were collected during the day at high tide, by sub-surface horizontal hauls with a conical net of mesh size $200 \mu \mathrm{m}$ and mouth diameter $60 \mathrm{~cm}$. A calibrated flow-meter was mounted centrally in the mouth of the net. The samples were preserved in $4 \%$ buffered formalin.

The temperature and salinity were measured using a Beckman thermosalinometer $\left(0.1{ }^{\circ} \mathrm{C}\right)$. Pluviometric data were provided by $\mathrm{Mr}$. Luis Carlos Austin ( $6^{\circ}$ DISME - National Institute of Meteorology of Rio de Janeiro). Dissolved oxygen was measured according to APHA (1985).

The samples were divided into fractions with a Folsom splitter (McEwen et al. 1957), and replicated subsamples containing at least 100 individuals were taken for the analysis (Frontier, 1981). The taxon abundance per cubic meter and species composition were determined for all the samples. The copepods were identified to the species level whenever possible, according to
Björnberg (1981) and Bradford-Grieve et al. (1999). The total density of each species was estimated from the adults and copepodites. Shannon's diversity index (Shannon, 1948) was calculated to evaluate the degree of organization of the copepod community.

The analysis of variance (ANOVA) was used at a significance level of $\mathrm{p}=0.05$ to identify the statistical differences among the sampling stations. All the data were evaluated for the normality and homogeneity prior to the analysis. A Principal Component Analysis (PCA) was performed to assess the main trends of the variability in the data. The PCA included the biotic and abiotic variables averaged for all the stations in the same cruise (copepod density; diversity; density of the species which, combined, represented $80 \%$ of total copepod abundance; temperature; salinity and dissolved oxygen). The data were log-transformed $[\log (x+1)]$ to obtain a homoscedastic data distribution (Legendre and Legendre, 1983). The correlation between the biotic and abiotic variables was estimated using the $r$-Pearson index $(\mathrm{p}=0.05)$.

\section{RESULTS}

\section{Environmental data}

The salinity varied over the sampling area. The lowest salinity was found in the inner station of the bay near the mouth of the Passagem River (station 3 ), one of the entrances of the estuarine system in the rainy season. Higher salinities found in the inner stations of the bay reflected the penetration of the saline wedge (Table 1).

The precipitation followed the normal pattern (rainy summer and dry winter), except during 1994 and 1996, when summer precipitation was below average (206.8 mm annually) (Fig. 1).

The water temperature maxima were recorded during the early autumn of 1995 and 1996, and minima in the winter of 1997. During the survey period, the highest water temperatures were found inside the bay, showing discernible spatial variation (Table I).

The station located near the Passagem River had higher values of dissolved oxygen which could be explained by the frequent renewal of the water because of the proximity of the open sea (Table I). 
Precipitation mm

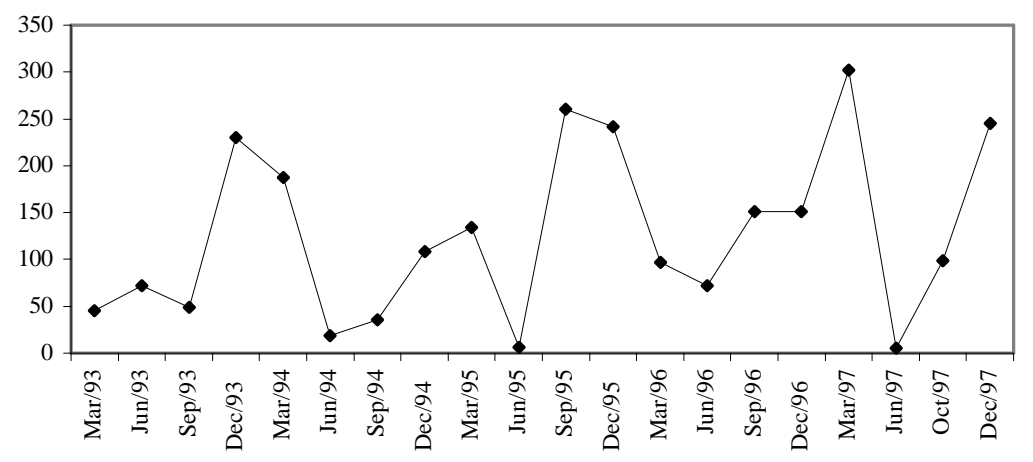

Figure 1- Precipitation measured during the cruises.

Table 1 - Minimum, maximum, mean and standard deviation of the copepod density (ind.m ${ }^{-3}$ ), temperature $\left({ }^{\circ} \mathrm{C}\right.$ ), salinity and dissolved oxygen (mg. $\left.\mathrm{L}^{-1}\right)$ in Espírito Santo Bay during a 5-year period (1993-1997).

\begin{tabular}{|c|c|c|c|c|c|c|c|c|}
\hline \multicolumn{9}{|c|}{ Stations } \\
\hline Parameters & 1 & 2 & 3 & 4 & 5 & 6 & 7 & 8 \\
\hline \multicolumn{9}{|l|}{ Salinity } \\
\hline Min & 28.1 & 28.4 & 27.5 & 28.2 & 30.4 & 30.1 & 32.2 & 32.3 \\
\hline Max & 37.1 & 37.0 & 37.2 & 37.2 & 37.0 & 37.2 & 37.5 & 37.5 \\
\hline Mean & 34.5 & 34.3 & 33.5 & 34.6 & 34.7 & 35.0 & 35.6 & 36.0 \\
\hline S.D. & 2.1 & 2.3 & 2.5 & 2.2 & 1.8 & 1.8 & 1.6 & 1.6 \\
\hline \multicolumn{9}{|l|}{ Temperature } \\
\hline Min & 22.2 & 22.4 & 22.6 & 22.3 & 21.3 & 21.8 & 20.9 & 20.1 \\
\hline Max & 26.0 & 26.0 & 28.7 & 26.1 & 25.7 & 25.3 & 25.4 & 25.8 \\
\hline Mean & 23.9 & 23.9 & 24.7 & 23.7 & 23.3 & 23.3 & 23.0 & 23.1 \\
\hline S.D. & 1.1 & 1.0 & 1.7 & 1.2 & 1.1 & 1.0 & 1.0 & 1.6 \\
\hline
\end{tabular}

Dissolved

oxygen

$\begin{array}{lcccccccc}\text { Min } & 5.3 & 5.2 & 5.8 & 6.0 & 6.1 & 5.3 & 6.2 & 5.8 \\ \text { Max } & 12.8 & 12.0 & 11.8 & 11.4 & 11.0 & 10.3 & 8.8 & 11.2 \\ \text { Mean } & 7.3 & 7.1 & 7.1 & 7.0 & 6.9 & 6.8 & 6.8 & 7.0 \\ \text { S.D. } & 1.8 & 1.6 & 1.3 & 1.2 & 1.1 & 1.0 & 0.6 & 1.2\end{array}$

Copepod

density

\begin{tabular}{lcccccccc} 
Min & 456.1 & 119.1 & 1478.0 & 658.0 & 951.7 & 68.9 & 68.3 & 69.7 \\
Max & 35994.2 & 57754.1 & 70406.0 & 55123.4 & 26126.9 & 26708.2 & 14559.2 & 10279.9 \\
Mean & 11853.8 & 15119.2 & 13041.8 & 13379.0 & 7027.1 & 5522.6 & 3876.0 & 2857.9 \\
S.D. & 11965.7 & 15781.7 & 17731.7 & 15534.7 & 6383.4 & 6660.8 & 3901.9 & 2990.7 \\
\hline
\end{tabular}

The copepod community

The copepods were the predominant group, representing more than $85 \%$ of the total zooplankton. There was a discernible spatial variation in overall copepod density. Based on the ANOVA, the copepod density was different among the sampling stations $(\mathrm{p}=0.05)$. It grouped the inner stations (1, 2, 3 and 4) separated from those located outside the bay (stations 5, 6, 7 and 8 ). The copepod density inside the bay ranged between 119 and 70,406 ind. $\mathrm{m}^{-3}$ (stations 1, 2, 3 and 4) and outside between 68 and 26,708 ind. ${ }^{-3}$ 
(stations 5, 6, 7 and 8). Inside the bay, stations 1 (west of Camburi Beach) and 3 (near the Passagem River channel) had the lowest copepod density (lower than 13,050 ind. $\mathrm{m}^{-3}$ ). The overall mean copepod density was 9,085 ind. ${ }^{-3}$, with abundance peaks (up to a mean of 15,000 ind. $\mathrm{m}^{-3}$ ) occurring in the summer and autumn during the first three years (1993 through 1995), following the periods of highest precipitation. During 19961997, the abundance pattern changed. The highest densities were found in the winter (Fig. 2).

The diversity showed the highest values (up to 2.6 bits.ind ${ }^{-1}$ ) in the autumn and spring of 1994, and summer of 1995 and 1997. The lowest values were found during the winter of 1997 (1.2 bits.ind $\left.{ }^{-1}\right)$ (Fig. 2).

Forty-six taxa of the copepods were recorded, 25 belonging to the order Calanoida, with an overall dominance of the species in the families Acartiidae, Paracalanidae and Temoridae (Table
2). The copepod assemblages were numerically dominated by the estuarine and estuarine/marine copepods, including Acartia lilljeborgi, Paracalanus quasimodo, Oithona hebes, Temora stylifera and Parvocalanus crassirostris. These species represented $93 \%$ of the total density of the copepods collected (Table 2).

The pronounced annual cycles were also apparent for the total density of the copepods, although not for the most copepod species. A. lilljeborgi showed the widest seasonal variability (Fig. 3). This species occurred in all the samples, and was usually the most abundant species (up to $48 \%$ of the total copepods), except in March 1993, September 1994, June and December 1995, and October and December 1997. In these months, the diversity was highest; $T$. stylifera and $P$. quasimodo were the other relatively common species.

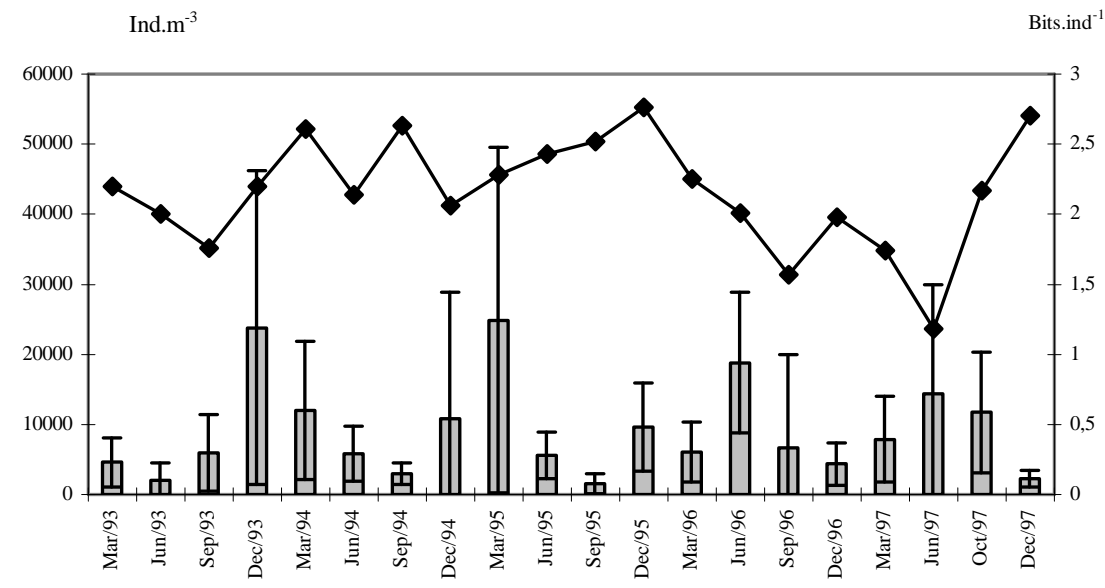

Figure 2 - Mean total copepod abundance $\left(\right.$ Ind. $\mathrm{m}^{-3}$ ), and species diversity $\left(\right.$ Bits.ind ${ }^{-1}$ ) values for each cruise (bar=mean; whisker=S.D.).

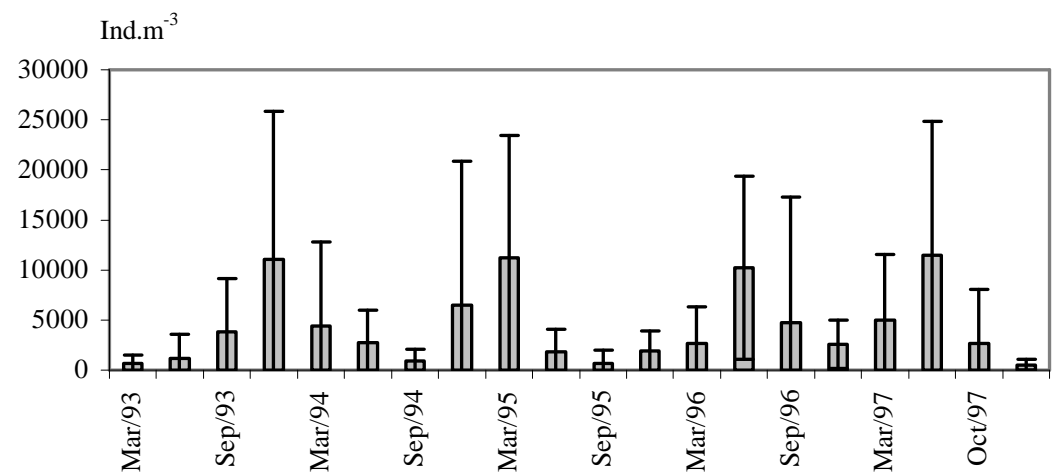

Figure 3 - Abundance of the dominant copepod species Acartia lilljeborgi during the sampling period in Espírito Santo Bay, during each cruise (bar=mean; whisker=S.D.). 
Table 2 - Minimum, maximum, mean (ind. $\mathrm{m}^{-3}$ ) and percentage occurrence $(\%)$ of the copepod taxa sampled in Espírito Santo Bay during a five-year period (1993-1997).

\begin{tabular}{|c|c|c|c|c|}
\hline Species & Min. & Max. & Mean & $\%$ \\
\hline Order Calanoida & 0.04 & 1144.26 & 161.52 & 1.78 \\
\hline Family Calanidae & 0.56 & 108.79 & 12.56 & 0.14 \\
\hline Calanoides carinatus & 0.01 & 299.60 & 18.57 & 0.20 \\
\hline Nannocalanus minor & 6.68 & 6.68 & 0.33 & 0.004 \\
\hline Neocalanus robustior & 0.15 & 0.15 & 0.01 & 0.0001 \\
\hline Acartia lilljeborgi & 505.98 & 11476.60 & 4337.27 & 47.75 \\
\hline Acartia sp. & 6.77 & 6.77 & 0.34 & 0.004 \\
\hline Paracalanus quasimodo & 0.00 & 6294.35 & 1482.22 & 19.58 \\
\hline Parvocalanus crassirostris & 126.25 & 3150.62 & 729.63 & 8.03 \\
\hline Paracalanus aculeatus & 1.52 & 13.55 & 0.89 & 0.01 \\
\hline Paracalanus parvus & 3.75 & 3.75 & 0.19 & 0.002 \\
\hline Calocalanus sp. & 2.09 & 2.09 & 0.10 & 0.001 \\
\hline Clausocalanus furcatus & 4.90 & 6.77 & 0.58 & 0.01 \\
\hline Ctenocalanus citer & 0.29 & 0.29 & 0.01 & 0.0002 \\
\hline Temora stylifera & 21.57 & 3962.65 & 734.81 & 8.09 \\
\hline Pseudodiaptomus acutus & 0.26 & 200.75 & 23.11 & 0.25 \\
\hline Subeucalanus pileatus & 1.05 & 72.16 & 14.91 & 0.16 \\
\hline Subeucalanus subtenuis & 9.20 & 9.80 & 0.95 & 0.01 \\
\hline Subeucalanus sp. & 0.65 & 63.83 & 10.71 & 0.12 \\
\hline Centropages velificatus & 0.34 & 318.25 & 23.79 & 0.26 \\
\hline Calanopia americana & 0.37 & 38.39 & 7.32 & 0.08 \\
\hline Family Pontellidae & 2.09 & 8.72 & 0.97 & 0.01 \\
\hline Labidocera fluviatilis & 0.01 & 0.10 & 0.01 & 0.0001 \\
\hline Nauplii & 0.37 & 45.07 & 9.65 & 0.11 \\
\hline Damaged animals & 0.67 & 9.99 & 1.86 & 0.02 \\
\hline \multicolumn{5}{|l|}{ Order Cyclopoida } \\
\hline Oithona hebes & 78.15 & 4558.81 & 827.83 & 9.11 \\
\hline Oithona oculata & 2.29 & 188.97 & 27.14 & 0.30 \\
\hline Oithona plumifera & 0.15 & 27.82 & 4.07 & 0.04 \\
\hline Oithona similis & 2.78 & 2.78 & 0.14 & 0.002 \\
\hline Oithona setigera & 2.84 & 12.14 & 0.75 & 0.01 \\
\hline Oithona sp. & 0.57 & 8.13 & 1.13 & 0.01 \\
\hline Nauplii & 0.47 & 870.87 & 58.09 & 0.64 \\
\hline \multicolumn{5}{|l|}{ Order Poecilostomatoida } \\
\hline Corycaeus giesbrechti & 12.87 & 984.50 & 166.25 & 1.83 \\
\hline Corycaeus speciosus & 4.01 & 13.59 & 0.88 & 0.01 \\
\hline Farranula gracilis & 0.06 & 40.89 & 5.74 & 0.06 \\
\hline Oncaea venusta & 0.31 & 8.91 & 0.61 & 0.01 \\
\hline Oncaea media & 3.03 & 3.03 & 0.15 & 0.002 \\
\hline Oncaea curta & 0.29 & 0.29 & 0.01 & 0.0002 \\
\hline Copilia mirabilis & 0.05 & 5.10 & 0.43 & 0.005 \\
\hline Family Clausidiidae & 0.81 & 0.81 & 0.04 & 0.0004 \\
\hline Hemicyclops thalassius & 0.04 & 27.92 & 1.77 & 0.02 \\
\hline Sapphirina nigromaculata & 4.00 & 8.77 & 0.64 & 0.01 \\
\hline \multicolumn{5}{|l|}{ Order Harpacticoida } \\
\hline Euterpina acutifrons & 5.81 & 485.21 & 111.86 & 1.23 \\
\hline Macrosetella gracilis & 4.86 & 4.86 & 0.24 & 0.003 \\
\hline Parasitic Copepoda & 0.01 & 22.32 & 3.98 & 0.04 \\
\hline Order Monstrilloida & 0.01 & 0.01 & 0.002 & 0.00002 \\
\hline
\end{tabular}




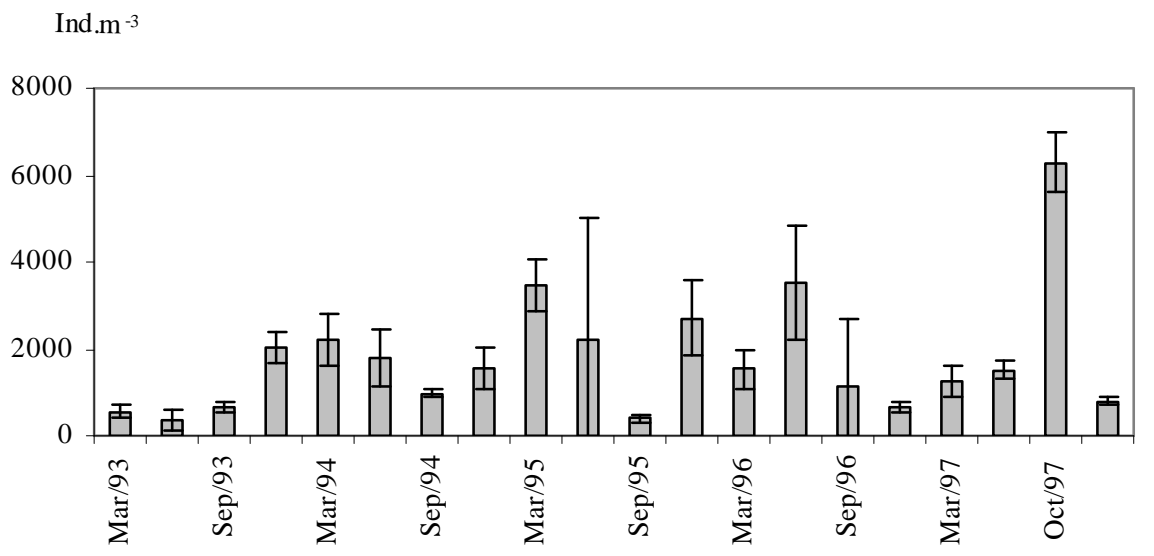

Figure 4 - Abundance of the dominant copepod species Paracalanus quasimodo during the sampling period in Espírito Santo Bay, during each cruise (bar=mean; whisker=S.D.).

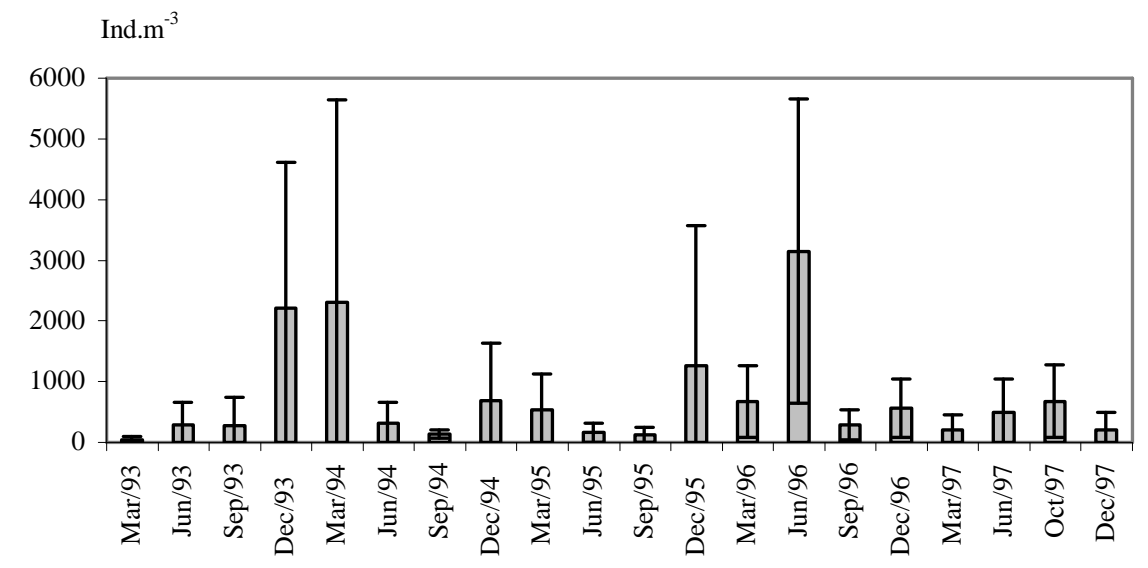

Figure 5 - Abundance of the dominant copepod species Parvocalanus crassirostris, during the sampling period in Espírito Santo Bay, during each cruise (bar=mean; whisker=S.D.).

Two species of the family Paracalanidae $(P$; quasimodo, up to $20 \%$ and $P$; crassirostris, up to $8 \%$ of the total copepods) were very abundant (Table 2). P. quasimodo reached peak numbers in March 1995, June 1996 and October 1997 (Fig. 4). This species was more abundant than A. lilljeborgi in September 1994, June and December 1995, and October and December 1997. P. crassirostris occurred in relatively low densities, with the exception of March 1994 and June 1996 when it reached the densities of more than 2000 ind. $\mathrm{m}^{-3}$ (Fig. 5).
The family Oithonidae was represented by five species, Oithona hebes and $O$; oculata being the most numerous. The estuarine-marine copepod $O$. hebes comprised up to $9 \%$ of the total copepod abundance and reached peak numbers in December 1993, March 1995, March and June 1996, and October 1997 (Fig. 6a and 6b).

Temora stylifera reached peaks in March and December 1993 and March 1995 (Fig. 7). This species comprised up to $8 \%$ of the total copepod abundance, and dominated the copepod population in March 1993, when the mean temperature was $23.7{ }^{\circ} \mathrm{C}$ and the salinity was 34.6. 
a)

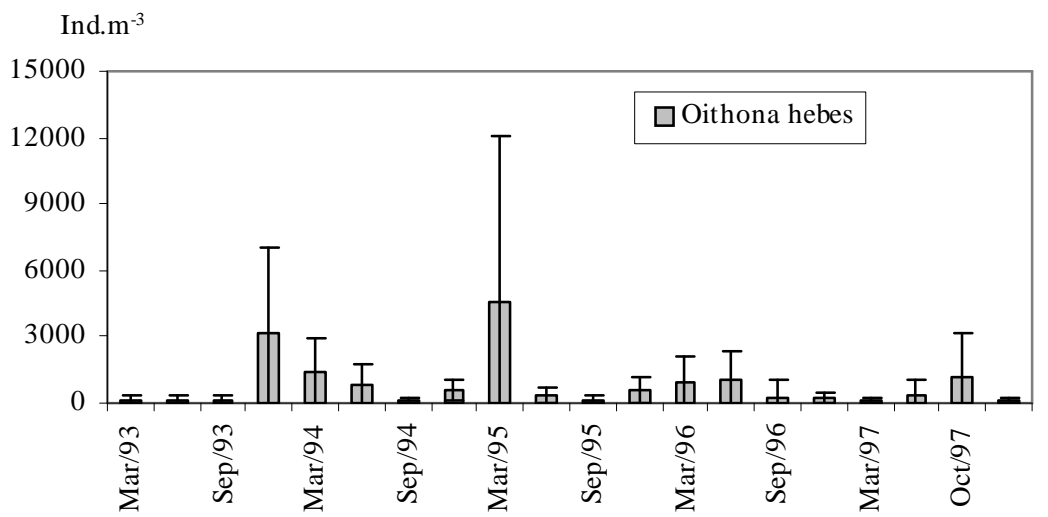

Ind. $m^{-3}$

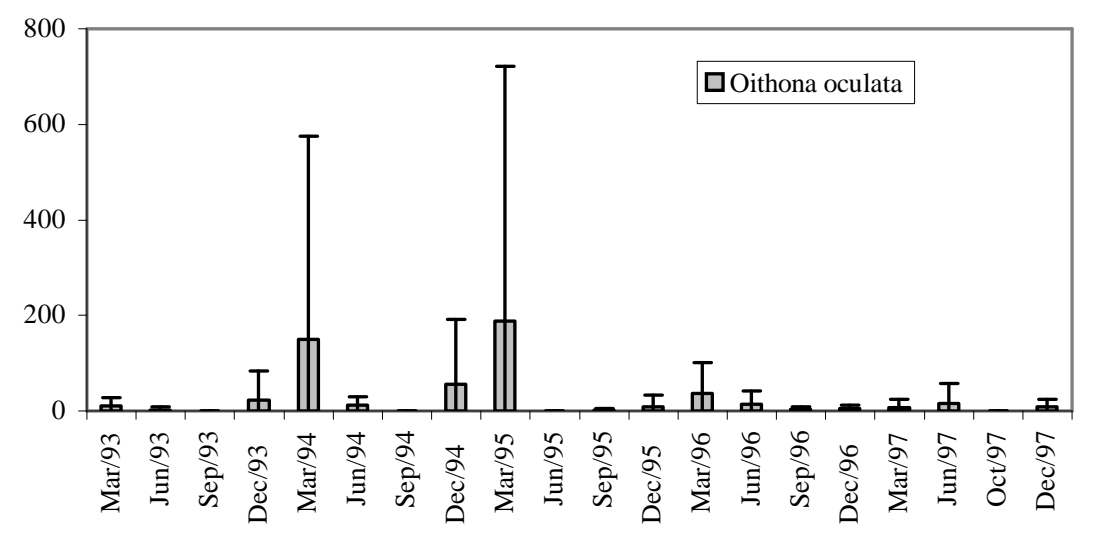

b)

Figure 6a and $6 \mathbf{b}$ - Abundances of the dominant copepod species (a) Oithona hebes and (b) Oithona oculata, during the sampling period in Espírito Santo Bay, during each cruise (bar=mean; whisker=S.D.).

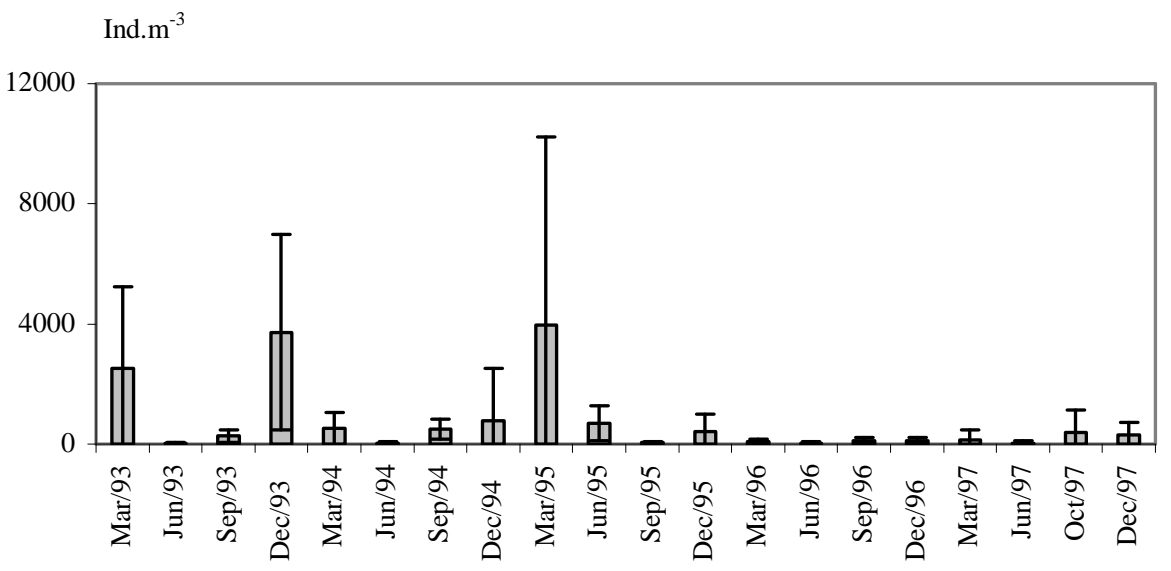

Figure 7 - Abundance of the dominant copepod species Temora stylifera, during the sampling period in Espírito Santo Bay, during each cruise (bar=mean; whisker=S.D.). 
a)
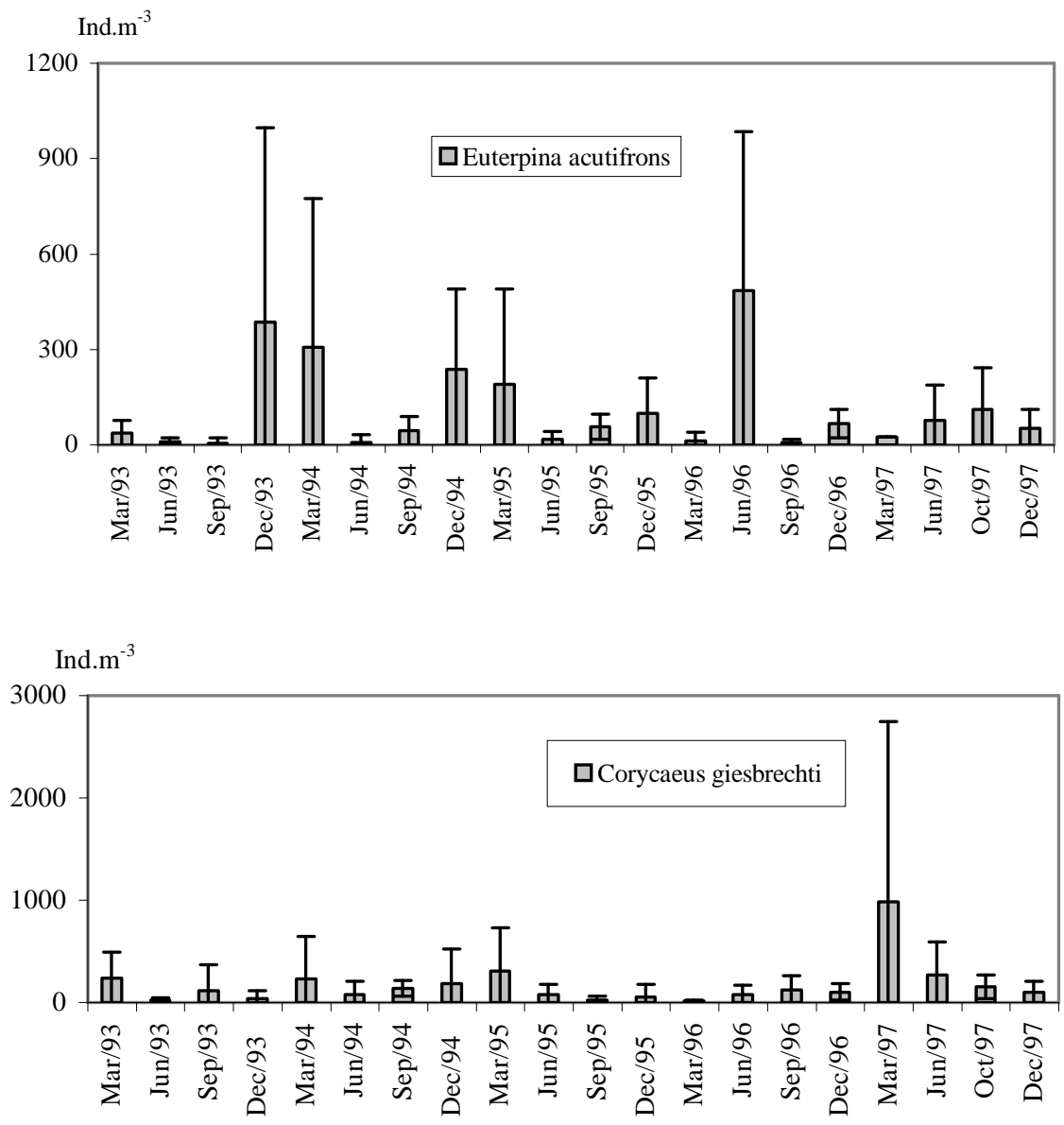

b)

Figure 8a and 8b - Abundances of the dominant copepod species (a) Euterpina acutifrons and (b) Corycaeus giesbrechti, during the sampling period in Espírito Santo Bay, during each cruise (bar=mean; whisker=S.D.).

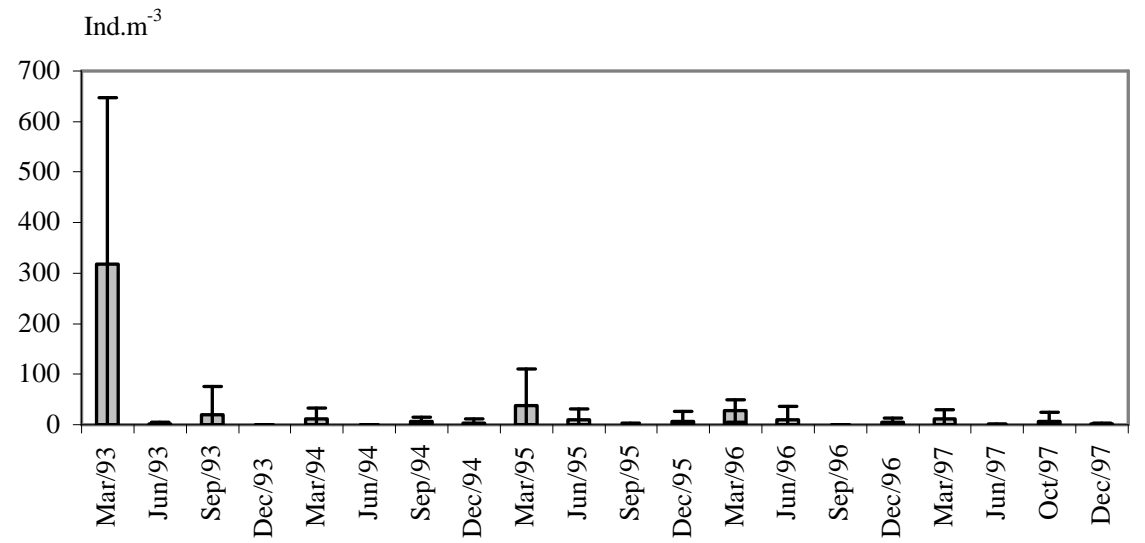

Figure 9 - Abundance of the dominant copepod species Centropages furcatus, during the sampling period in Espírito Santo Bay, during each cruise (bar=mean; whisker=S.D.). 
The marine euryhaline copepods Euterpina acutifrons, Corycaeus giesbrechti (Fig.s 8a and $8 b)$ and the coastal-marine Centropages furcatus (Fig. 9) occurred in almost all the samples, but in low densities.

The copepod population of Espírito Santo Bay showed the coastal and estuarine characteristics, e.g., with the occurrence of such species as $H$. thalassius, O. oculata, Pseudodiaptomus acutus and Labidocera fluviatilis. The occurrence of the inner- and coastal-water species was chiefly associated with the lower salinities found inside the bay.

The presence of the tropical species such as Oncaea venusta, Clausocalanus furcatus, Subeucalanus subtenuis, $O$. plumifera and
Macrosetella gracilis could be associated with the marine influence in the area. These species occurred outside the bay, and were carried into it with the entrance of the water, which caused increased salinity and temperature.

Two cold-water species (Ctenocalanus citer and Calanoides carinatus) were found outside the bay. Ctenocalanus citer and Calanoides carinatus occurred in the spring 1993 and in summer from 1994 to 1997, and both were collected in the water of temperatures from 22.4 to $24.8^{\circ} \mathrm{C}$.

The relationship between the copepod assemblage and the environmental variables was obtained through the PCA analysis, which disclosed two factors (Fig. 10) that together explained $51 \%$ of the variation in the copepod assemblage.

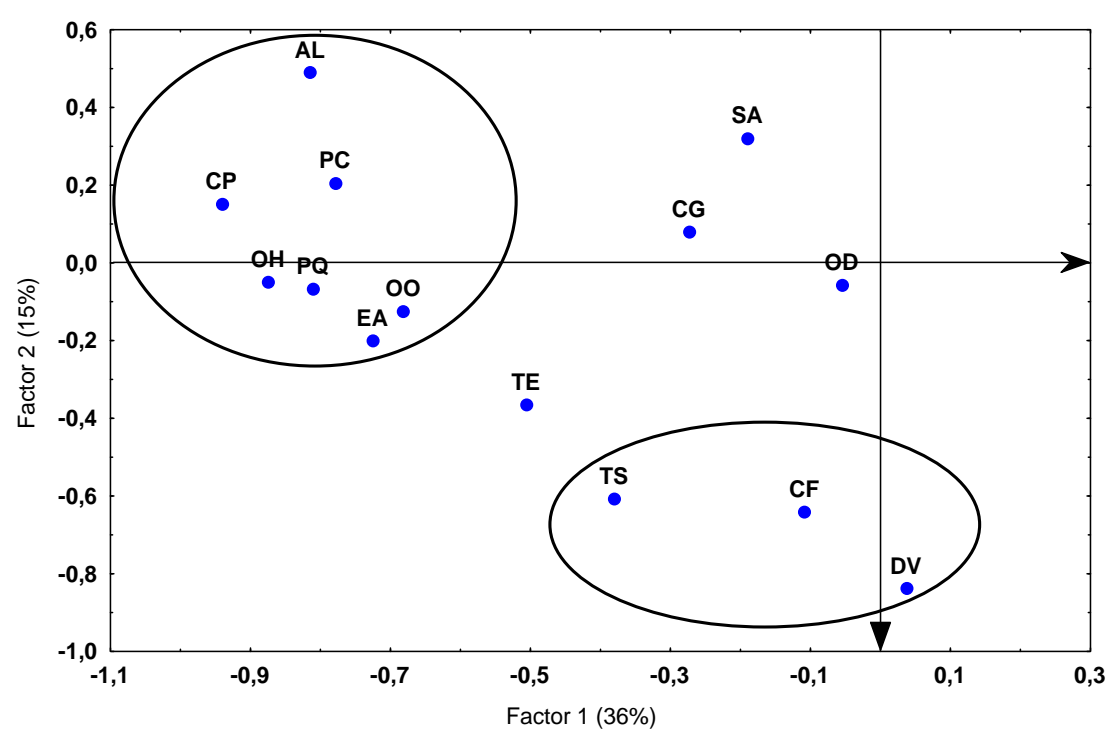

Figure 10 - Scatter plot of variables related to Factors I x II over the five-year sampling period. Symbols for the copepod taxa and environmental parameters included in the multivariate analysis: CP - Copepods, AL - Acartia lilljeborgi, PQ - Paracalanus quasimodo, PC - Parvocalanus crassirostris, TS - Temora stylifera, OH - Oithona hebes, OO - Oithona oculata, CG - Corycaeus giesbrechti, EA - Euterpina acutifrons, CF - Centropages furcatus, DV - Diversity, TE - Temperature, SA - Salinity and OD - Dissolved oxygen.

Factor I (36\%) was the temporal factor generated by the variation in the copepod community during the five years of the sampling. The maximum copepod abundance occurred in the summer 1993/94, autumn 1994/95 and winter 1996, associated with the higher mean temperatures and salinity (up to $25.6{ }^{\circ} \mathrm{C}$ and 36.7 in autumn 1995). The variations were related to the abundances of
A. lilljeborgi, $O$. hebes, $P$. quasimodo, $P$. crassirostris, O. oculata, and E. acutifrons. These species were associated $(\mathrm{r}>0.40)$, and the abundance of $A$. lilljeborgi acted to decrease the community diversity. Factor II $(15 \%)$ reflected the influence of the water masses on the copepod assemblage, relating the specimens to the temporal variations in temperature and salinity. These 
parameters were especially related to the abundances of $P$. crassirostris and A. lilljeborgi. These species showed an affinity to high salinity in the spring 1996, and low temperature in winter 1997. C. furcatus and T, stylifera were associated with the inverse conditions in the autumn 1993. The diversity ratio (up to 2.2 bits.ind $^{-1}$ ) could be associated with the presence of a more-structured copepod assemblage in the region. In these months, the reduction of the Acartia lilljeborgi density acted to increase the community diversity $(\mathrm{r}=-0.54)$.

\section{DISCUSSION}

Espírito Santo Bay is a typical estuarine system, dominated by the coastal waters. The spatial and temporal variations of the environmental variables (salinity, temperature and dissolved oxygen) are typical for the region (Dias, 1994; Pereira et al. 2000; Jesus et al. 2004) and other estuarine systems of southeastern Brazil (Fernandes et al . 2002; Gomes et al. 2004).

The mean copepod abundance during the present study period was slightly lower than that estimated for an earlier period (1986-1987) by Dias (1994), who found a mean of 9,248 ind. $\mathrm{m}^{-3}$. Dias used the same sampling methodology to study the copepod composition in stations located inside the bay. The distribution of the density the values found inside the bay in the present study were similar to that found by Dias (1994). Inside the bay, the stations west of Camburi Beach and near the Passagem River channel showed the lowest copepod density. The results reflected the environmental conditions of these areas, impacted by the human activities such as the industrial, port and household wastes (Nalesso and Mazioli, 2000; Nassar et al. 2003; Jesus et al. 2004). Despite the reduction in the copepod density and the maintenance of the lowest density in the station located near these degraded areas (Camburi Beach and Passagem River channel), the copepod population of the Espírito Santo Bay maintained its characteristics. The copepod assemblage was composed of the estuarine and estuarine/marine species, with the occurrence of the inner- and coastal-water species and the presence of the tropical species.

The temporal variations of the environmental variables could be related to the abundance of almost all the species, during the five years of sampling, with the dominant species alternating. $A$. lilljeborgi was the most abundant species except in the dry months (when precipitation was lower than $99 \mathrm{~mm}$ ) and in the months where the salinity values were the lowest of the period. A. lilljeborgi has been the most abundant Acartia species in Brazilian estuaries. Acartia species are indicators of the coastal waters, and are often dominant among the copepods in the warm coastal and estuarine waters of higher salinity (Björnberg, 1981; Lopes, 1994; Ramaiah and Nair, 1997). In the months when the density of A. lilljeborgi decreased, $T$. stylifera and $P$. quasimodo were the dominant species. The family Paracalanidae generally occurs in the coastal waters, and Temora stylifera is associated with the coastal and shelf waters off Brazilian coasts (Björnberg, 1981; Bradford-Grieve et al. 1999). These abundances levels were similar to other findings for the species along the southeastern Brazilian coast (Lopes, 1994; Wandeness et al. 1997; Silva et al. 2004).

The presence of the cold-water species in the rainy months has not been reported in previous studies, e.g., Bonecker et al. $(1987,1991)$ and Dias (1994). $C$. carinatus was a typical member of the zooplankton upwelling communities, reaching higher abundances in the summer.

The qualitative composition of the copepod fauna studied here was different from that reported by Dias (1994), who found only 22 copepod species, of which A. lilljeborgi, $P$. quasimodo and $O$. hebes represented $93 \%$ of the total number. The observed relationships of the salinity with the fluctuations in the copepod abundance reflected the changes in the proportions of different water masses, such as the penetration of more saline water into the inner bay. Consequently, there was a small difference in the densities and diversity in comparison with the values found during 1986 and 1987.

Espírito Santo Bay and its surroundings, like other urbanized and industrialized coastal areas, have suffered inputs of the industrial and urban waste. The effects of the degradation caused by the human activities on the marine ecosystems normally are a decrease in the biological diversity and loss of some species (Silva et al. 2004). These effects were not observed in the present study in the areas affected by the industry and household wastes. Although the copepod density decreased, the values of the diversity increased in the present study. 
In this five-year data, the variability observed in relation to the abundance, diversity and species composition did not affect the dominant species, which were the same as those found in 1986-1987 by Dias (1994). The difference in the qualitative composition of the copepod fauna in relation to the previous study done in the same region could be associated with the environmental microvariations (temperature and salinity) that were characteristic of the coastal regions, and the movements of the saline waters into the bay.

\section{ACKNOWLEDGEMENTS}

This study was conducted as part of a monitoring program of Espírito Santo Bay developed by the Centro de Pesquisas do Mar (CEPEMAR). Authors thank the Companhia Vale do Rio Doce (CVRD) for providing some of their zooplankton material and Dra. Janet Reid for reading the manuscript and valuable remarks.

\section{RESUMO}

Este trabalho descreve a estrutura da comunidade de copépodes em relação às condições hidrográficas da baía do Espírito Santo, no período de 1993 a 1997. As amostras do zooplâncton foram obtidas através de arrastos horizontais, quatro vezes ao ano, com uma rede de $200 \mu \mathrm{m}$. A temperatura, a salinidade e o oxigênio dissolvido foram determinados nas amostras de água. A densidade média dos copépodes foi de 9.085 ind. $\mathrm{m}^{-3}$, com picos superiores a 15.000 ind. $\mathrm{m}^{-3}$, durante o verão e o outono de 1993 a 1995. Utilizou-se a PCA para relacionar as variáveis ambientais à distribuição dos copépodes. A comunidade dos copépodes, principalmente as altas densidades das espécies Acartia lilljeborgi, Oithona hebes, Oithona oculata, Paracalanus quasimodo, Parvocalanus crassirostris e Euterpina acutifrons foram relacionados à diminuição da diversidade. As variações espaçotemporais da temperatura e da salinidade influenciaram a abundância das espécies durante os cinco anos de coleta, com a alternância das espécies dominantes.

\section{REFERENCES}

American Public Health Association (1985), Standard Methods for the Examination of Water and Wastewater. $16^{\text {th }}$ ed, New York.

Bassani, C.; Bonecker, A.C.T.; Bonecker, S.L.C.; Nogueira, C.R.; Reis, J.M.L. and Nascimento, L.R. (1999), Plâncton no litoral norte do estado do Rio de Janeiro $\left(21^{\circ} 00^{\prime}\right.$ a $\left.23^{\circ} 30^{\prime} \mathrm{S}\right)$. Análise e síntese do conhecimento. In - Ecologia dos Ambientes Costeiros do Estado do Rio de Janeiro, ed. S.H.G. Silva and H.P. Lavrado. O ecologia Brasiliensis, 7, 99-120.

Bonecker, S.L.C.; Bonecker, A.C.T.; RiveraTenenbaum, D.; Bassani-Bastos, C.T.; Nogueira, C.R.; Santos, L.H.S.; dos Reis, J.M.L.; Dias, C.O.; Reynier, M.V.; Dias, A. de S. and Coelho, M.J. (1987), Distribuição espaço-temporal das comunidades planctônicas na Baía do Espírito Santo (Brasil). $2^{\circ}$ Congresso Latinoamericano Ciencias do Mar, Anales Cientificos U.N.A.L.M. (Volumen Extraordinario), 2, 155-179.

Bonecker, S.L.C.; Bonecker, A.C.T.; Nogueira, C.T. and Reynier, M.V. (1991), Ecological studies at Espírito Santo bay, Brazil. Zooplankton communities. In - Proceedings of the Seventh Symposium on Coastal and Ocean Management, ed. O. T. Magoon; H. Converse; V. Tippie; L. T. Tobin and D. Clark. Coastal Zone '91, 4, 3268-3278.

Björnberg, T.S.K. (1981), Copepoda. In - Atlas del Zooplancton del Atlantico Sudoccidental y metodos de trabajo com el zooplancton marino, ed. D. Boltovskoy. INIDEP, Mar del Plata, Argentina: pp: 587-679.

Bradford-Grieve, J.M.; Markhaseva, E.I.; Rocha, C.E.F. and Abiahy, B. (1999), Copepoda. In - South Atlantic Zooplankton, ed. D. Boltovskoy. Backhuys Publishers, Leiden. Vol. II, pp: 869-1098.

Carmo, T.M.S. (1987), Os manguesais ao norte da baía de Vitória, Espírito Santo. Publicação ACIESP, 54-1, 173-194.

Carmo, T.M.S.; Perrone, E.C., Fundão, D. N.; Melo, R. M. S. and Zanotti-Xavier, S. (1994), Macrofauna de invertebrados do estuário do rio Santa Marta da Vitória, Vitória, ES. Publicação ACIESP, 87-1, 305314.

Christou, E.D. (1998), Interannual variability of copepods in a Mediterranean coastal area (Saronikos Gulf, Aegean Sea). Journal of Marine Systems, 15, 523-532

Dias, C.O. (1994), Distribuição e variação espaçotemporal dos copépodes na Baía do Espírito Santo (Vitória - E.S. - Brasil). Brazilian Archives of Biology and Technology, 37, 929-949.

Dias, C.O. (1999), Morphological abnormalities of Acartia lilljeborgi (Copepoda, Crustacea) in the Espírito Santo Bay (E.S. Brazil). Hydrobiologia, 394, 249-251. 
Dias, C.O.; Bonecker, S.L.C. and Nogueira, C.R. (1999), Variações na estrutura da comunidade Zooplanctônica próxima a Usina I da Central Nuclear Almirante Álvaro Alberto (CNAAA) - (Angra dos Reis-RJ-Brasil) - Ciclo 1980/81 e 1991/93. Brazilian Archives of Biology and Technology, 42(2), 223-232.

Fernandes, L.D. de A., Bonecker, S.L.C. and Valentin, J.L. (2002), Dynamic of decapod crustacean larvae on the entrance of Guanabara bay. Brazilian Archives of Biology and Technology, 45 (4), 491-498.

Frontier, S. (1981), Cálculo del error em el recuento de organismos zooplanctónicos. In - Atlas del Zooplancton del Atlántico Sudoccidental y métodos de trabajo com el zooplancton marino, ed. D. Boltovskoy. INIDEP, Mar del Plata, Argentina, pp. 163-167.

Gomes, C.L.; Marazzo, A. and Valentin, J.L. (2004), The vertical migration behaviour of two calanoid copepods, Acartia tonsa Dana, 1849 and Paracalanus parvus (Claus, 1863) in a stratified tropical bay in Brazil. Crustaceana, 77(8), 941-954.

Jesus, H.C. de; Costa, E.A.; Mendonça, A.S.F. and Zandonade, E. (2004), Distribuição de metais pesados em sedimentos do sistema estuarino da Ilha de Vitória, ES. Química Nova, 27(3), 378 - 386.

Legendre, L. and Legendre, P. (1983), Numerical Ecology. Elsevier, New York, pp. 419.

Lopes, R.M. (1994), Zooplankton distribution in the Guaraú River estuary (south-eastern Brazil). Estuarine, Coastal and Shelf Science, 39, 287-302.

Loureiro Fernandes, L.; Sterza, J.M.; Pereira, J.B. and Costa, D. (1998), Preliminary assessment of morphological alterations in the copepod Acartia lilljeborgi due to environmental changes in the Vitória estuarine system, Vitória, ES, Brazil. Nauplius, 6, 199-200.

McEwen, G.F.; Johnson, M.W. and Folsom, T.R. (1957), A statistical analysis of the performance of the Folsom plankton sample splitter, based upon test observations. Archives of Meteorology, Geophysics and Climatology, (Ser. A) 7, 502-527.

Nalesso, C.R. and Mazioli, C. (2000), Fauna macrobentônica da região entre-marés da praia de Camburi, Vitória, ES. Publicação ACIESP, 109(2), $156-163$.

Nassar, C.A.G; Salgado, L.T.; Yoneshigue-Valentin, Y. and Amado Filho, G.M. (2003), The effect of iron-ore particles on the metal content of the brown alga Padina gymnospora (Espírito Santo Bay, Brazil). Environmental Pollution, 123, 301-305.
Pereira, B.B; Almeida, H.G. de; Casto, L.L.M.; Vieira, G.R.A.S. and Joyeux, J.-C. (2000), Características físico-químicas da água na entrada do sistema estuarino da Baía de Vitória, ES. Publicação ACIESP, 109(2), 198-205.

Ramaiah, N. and Nair, V.R. (1997), Distribution and abundance of copepods in the pollution gradient zones of Bombay Harbour-Thana creek-Bassein creek, west coast of India. Indian Journal of Marine Sciences, 26, 20-25

Shannon, C.E. (1948), A mathematical theory of communication. Bell System Technical Journal, 27, 379-423, 623-656.

Schutze, M.L.M. and Ramos, J.M. (1999), Variação anual do zooplâncton na Baía da Guanabara e na região litorânea adjacente (Rio de Janeiro - Brasil) com especial referência aos copépodes. In - Ecologia dos Ambientes Costeiros do Estado do Rio de Janeiro, ed. S.H.G. Silva and H.P. Lavrado. Oecologia Brasiliensis, 7, 61-72.

Silva, A.P.; Neumann-Leitão, S. and Schwamborn, R. (2004), Mesozooplankton of an impacted bay in North Eastern Brazil. Brazilian Archives of Biology and Technology, 47(3), 485-493.

Tommasi, L.R. (1987), Poluição marinha no Brasil: síntese do conhecimento. Publicação do Instituto oceanográfico, São Paulo, 5, 1-30.

Valentin, J.L.; Tenenbaum, D.R.; Bonecker, A.C.T.; Bonecker, S.L.C.; Nogueira, C.R. and Villac, M.C. (1999), O sistema planctônico da Baía da Guanabara: síntese do conhecimento. In - Ecologia dos Ambientes Costeiros do Estado do Rio de Janeiro, ed. S.H.G. Silva and H.P. Lavrado. Oecologia Brasiliensis, 7, 35-59.

Wandeness, A.P.; Mattos, M.A.R. and Nogueira, C.S.R. (1997), Copepoda (Crustacea) of Guanabara Bay, Rio de Janeiro. I. Specific composition. Brazilian Archives of Biology and Technology, 40(2), 377-381.

Received: December 12, 2005; Revised: February 07, 2007; Accepted: February 01, 2008. 